\title{
Asas certainty dalam mekanisme pembayaran kewajiban bea perolehan hak atas tanah dan bangunan
}

\author{
Riskha Indah Respati ${ }^{1}$, Indah Dwi Qurbani ${ }^{2}$, R. Imam Rahmat Safi'i ${ }^{3 .}$
}

${ }^{1}$ Riskha Indah Respati; Fakultas Hukum Universitas Brawijaya; Jalan MT. Haryono No. 169; Malang; 65145; Jawa Timur; Indonesia.

${ }^{2}$ Indah Dwi Qurbani; Fakultas Hukum Universitas Brawijaya; Jalan MT. Haryono No. 169; Malang; 65145; Jawa Timur; Indonesia.

${ }^{3}$ R. Imam Rahmat Syafi'i; Fakultas Hukum Universitas Brawijaya; Jalan MT. Haryono No. 169; Malang; 65145; Jawa Timur; Indonesia.

\section{ART I C LEINFO}

\section{Article history:}

Received 2020-10-19

Received in revised form

2020-11-14

Accepted 2020-12-01

Kata kunci:

Asas Certainty; Hak Atas Tanah dan Bangunan; BPHTB.

\section{Keywords:}

Certainty Principle; Rights to Land and Buildings; BPHTB.

DOI: https://doi.org/10.26905/ idjch. v11i3. 4281.

\section{How to cite item:}

Respati, R., Qurbani, I., \& Syafi'i, R. (2020). Asas certainty dalam mekanisme pembayaran kewajiban perpajakan bea perolehan hak atas tanah dan bangunan. Jurnal Cakrawala Hukum, 11(3). 323-332. doi:10.26905/idjch.v11i3.4281.
Corresponding Author:

* Riskha Indah Respati.

E-mail address: riskhaindah.respati@gmail.com

\section{Abstrak}

Diperlukan pemahaman bagaimana seharusnya pengaturan tentang mekanisme pembayaran kewajiban perpajakan BPHTB sesuai dengan asas certainty serta mencerminkan kepastian hukum bagi wajib pajak. Terdapat adanya permasalahan yang muncul mengenai permohonan penelitian dan pemeriksaan BPHTB oleh fiskus yaitu Bapenda Kota Malang dalam pemenuhan kewajiban perpajakan BPHTB. Pada tindakan tersebut kerapkali melahirkan pertentangan atau permasalahan dalam pelaksanannya. Penelitian yuridis empiris adalah jenis penelitin yang dipergunakan dalam penelitian ini seraya menggunakan perdekatan perundang-undagn, pendektan koseptual, dan pendektan kasus. Pada haseil yang diperoleh dari riset di lapangan, Bapenda Kota Malang belum menerapkan asas certainty dalam mekanisme pembayaran kewajiban perpajakan BРНTB khususnya mengenai permohonan penelitian dan pemeriksaan BPHTB, sehingga pengaturan kedepan lebih mengacu pada Perda Kota Malang tentang BPHTB.

\section{Abstract}

It is necessary to understand how arrangements should be made for the payment mechanism for BPHTB tax obligations in accordance with certainty principles and reflect legal certainty for taxpayers. There are problems that arise regarding the request for research and inspection of BPHTB by the tax authorities, namely Bapenda Malang City in fulfilling BPHTB tax obligations. In these actions often cause conflicts or problems in their implementation. This type of research used in this reserch is about empircal juriidical research using the statutory approach, conceptual aproach, and case approach. The results in reality research show that Malang City Bapenda has not applied certainty principle in BPHTB tax liability payment mechanism especially regarding $B P H T B$ research requests and examinations, so that future regulations refer to Malang City Regional Regulation on ВРНTB. 


\section{Jurnal Cakrawala Hukum, Volume 11 No. 3 Desember 2020}

ISSN PRINT 2356-4962 ISSN ONLINE 2598-6538

\section{Pendahuluan}

Pembentukan instrument pajak tentunya tidak terlepas dari prinsip pemungutan pajak, salah satunya yaitu asas certainty. Menurut Rochmat Soemitro dan Dewi Kania Sugiharti dàlàm bukunya yàng berjudul "Asas Dan Dasar Perpajakan” yang menjelàskàn bàhwà kepastian hukum adalah tujuan yang ingin dicapai oleh setiap UU. Dalam membuat UU dan Peraturan, harus mengupayakan ketentuan yang didalamnya pasti, mudah dipahami, dan tidak berisi makna ganda atau memberkan kesempatan menafsirkan lain (Soemitro 2004). Asas certainty bertujuan supaya pemungutan pajak khususnya BPHTB tidak adanya penyelewengan dan tetap dalam prosedur yang sesuai. Dan pembuat UU lebih memperhatikan keadilan dalam pemungutan pajak.

Dalam kaitanya dengan persoalan pendapatan HAT serta bangunan, maka kepastian hukum guna "wajib pajak" merupakan salah satu pendekatan untuk melindungi wajib pajak. Dengan begitu dibutuhkannya regulasi hukim dengan selalu memperhatikan pertumbuhan masyrakat.

Perda Kota Malang mengatur mengatur halhal yang berkaitan dengan administrasi pemungutan. Pada Permohonan Penelitian dan Pemeriksaan BPHTB di Kota Malang merupakan tahapan dalam proses penelitian dan pemeriksaan data. Metode ini dimaksudkan agar menghimpunkan, mendapat, memenuhi, dan mengecek penaksiran BPHTB terutang yang terliput ke dalam pencatatan objekl dan subjek PBBP2 yang dilaksanakan oleh Bapenda Kota Malang. Agar dapat terciptanya pemungutan PBBP2 yang sesuai administrasi, adil dan merata, meningkatan kepastian dan perolehan PBBP2, serts meningkatan layanan untuk wajib pajak.

Persoalan timbul adanya tindakan permohonan penelitian dan pemeriksaan oleh fiskus yaitu Bapenda Kota Malang dalam pemenuhan kewajiban BPHTB. Permohonan penelitian dan pemeriksaan BPHTB mengakibatkan masalah dalam pelaksanaannya, dikarenakan timbul ketimpangan antara das Sollen dan das Sein. Di Kota Malang ter- dapat adanya kebijakan yang dikeluarkan oleh Bapenda dalam melakukan permohonan penelitian dan pemeriksaan BPHTB harus meneyelesaikan seluruh kewajiban perpajakan, yang mana harus menyelesaikan pembayaran PBBP2 seluruhnya, namun dalam Perda Kota Malang tentang BPHTB yang menyebutkan bahwa tidak adanya PBBP2 terutang selama 5 tahun terakhir.

Persoalan yang timbul diantaranya ketika BPD mengimplementasikan suutu Perdsa beralaskan pada otoritas dengan tidak berpedoman pada kaidah yang nyata hanya untuk mencapai tuntutan PAD karena sumber utama diperoleh dari BPHTB, tentunya hal ini pasti berakibat merusak iklim penanaman modal dalam masa yang lama. Secra sektoral pembetulan implementasi Perda berkenaan pajak yang nantinya inilah membawa dampak untuk menyelesaikan seluruh kewajiban perpajakan dalam permohonan penelitian dan pemeriksaan BPHTB yang dikeluarkan oleh BAPENDA teruntuk pelaksana bisnis dan membebani masyrakat yang terjadi lantaran termuat ketidkpastian pada regulasi tersbut.

Tidak hanya mengimplementasi, tetapi juga ketika BPD melakukan penderkatan atas pemahaman mengenai undang-undang perpajakan persoalan pajak BPHTB. Mengenai profit yang belum pasti dikantongi dari setisap penyetoran ketika pembellian tanah dan/atau bngunan. Sehingga banyak wajib pajak yang beranggapan tidak adil yang membuat WP menganggap tidak memiliki suatu kepastian terhadap total pajak yang semestinya dibayrkan.

Persoalan lainnya dipandang dari segi sosiologis pada pemda yang dapat mempengaruhi dengan menghalangi jalanannya pelaynan dan pembayaran BPHTB lantaran kerap kali wajib pajak tidak setor BPHTB pada saat yang telah ditentukan. Pengaktualan permohonan penelitian dan pemeriksaan pasti membutuhkan waktu yang tidak singkat yang merupakan akibat dari lambatnya pembayaran. Hal ini akan memperlama proses registrasi pemindahan HAT dan bangunan di BPN yang dapat memunculkan hukum yang tidak pasti 


\section{Asas certainty dalam mekanisme pembayaran kewajiban bea perolehan hak atas tanah dan bangunan}

Riskha Indah Respati, Indah Dwi Qurbani, R. Imam Rahmat Safi'i

kepada orang yang melakukan transaksi. Jalannya layanan pemindahan BPHTB dalam prakteknya serta penyerahan berkas persyaratan memiliki kurun waktu sekitar 3-7 hari kerja.

Perlu diketahui bahwa BPHTB memiliki peranan yang cukup signifikan bagi Pendapatan Asli Daerah (PAD). Seperti misalnya di Kota Malang terdapat adanya kebijakan yang dikeluarkan oleh Badan Pendapatan Daerah dalam melakukan permohonan penelitian dan pemeriksaan BPHTB harus meneyelesaikan seluruh kewajiban perpajakan, yang mana harus menyelesaikan pembayaran Pajak Bumi dan Bangunan Perkotaam seluruhnya, namun dalam Perda Kota Malang tentang BPHTB yang menyebutkan bahwa tidak terdapat PBBP2 terutang selama 5 tahun terakhir.

\section{Metode}

Jenis penelitian ini adalah penelitian empiris, yaitu melakukan penelitian langsung ke Bapan Pendapatan Daerah Kota Malang. Pendekatan yang dipakai dalam penelitian ini adalah pendekatan yuridis sosiologis. Pendekatan Yuridis sosiologis adalah penelitian hukum yang menggunakan data sekunder sebagai data awalnya, yang kemudian di lanjutkan dengan data primer atau data lapangan, meneliti efektivitas suatu undangundang dan penelitian yang ingin mencari hubungan (korelasi) antara berbagai gejala atau variable sebagai alat pengumpul datanya, terdiri dari studi dokumen, pengamatan (observasi), dan wawancara (interview).

\section{Pembahasan}

\subsection{Penerapan asas certainty terhadap meka- nisme pembayaran kewajiban perpajak- an BPHTB}

\section{Berlakunya asas certainty terhadap wajib pajak}

Asas certainty yang dikemukakan Tunggul Anshari adalah adanya kepastian bagi wajib pajak, oleh karena itu peraturan pajak mampu menciptakan kepastian terhadap wajib pajak. Untuk itu, pembuat undang-undang pajak harus menguasai legal drafting dan yang harus menjadi perhatian dalam pembuat undang-undang agar ada kepastian hukum, yakni uu yang dibuat harus nyata, mudah dipahami, serta tidak berisi makna ganda atau memberikan kesemptan menafsirkan lain, memberikan pengertian yang mudah dipahami, uraian yang limitatif lebih diutamakan daripada yang emunsiatif, proteksi hukum pada wajib pajak yang merupakan bentuk pertanggungan hukum, terdapat makna objek pajak yang absolut, kepastian total pajak yang wajib dilunasi, makna orang yang dapat dipungut pajak memiliki kepastian, serta krpatsian metode dan waktu yang tepat memenuhi pajak (Anshari, 2007).

Dalam membuat peraturan, pembuatnya harus memperhatikan keadilan. Dalam hal ini asas certainty secara ideal belum diterapkan dalam peraturan perundiang-undangan tentang pemungutan pajak di Kota Malang karena belum tercapainya suatu kepastian hukum bagi wajib pajak di Kota Malang dalam melakukan pembayaran kewajiban perpajakan permohonan BPHTB yang mana wajib pajak harus menyelesaikan tunggakan/seluruh kewajiban pembayaran PBBP2 dalam hal ini tidak diatur di dalam perundangundangain, sedangkan di dalam Perda Kota Malang tentang BPHTB menjelaskan dalam penelitian dan pemeriksaan tidak ada pajak terutang PBBP2 selama 5 tahun terakhir.

\section{Mekanisme pembayaran kewajiban perpajakan BPHTB}

Mekanisme Pembayaran Kewajiban Perpajakan BPHTB adalah sebagai berikut: 1. WP nantinya akan mendapatkan BPHTB yang sudah dilengkapi dengan benar. Surat yang dipakai wajip pajak dalam melangsungkan pemenuhan atau penyetoran pajak yang wajib dilunasi serta melakukan pemberitahuan mengenai keterangan 


\section{Jurnal Cakrawala Hukum, Volume 11 No. 3 Desember 2020}

ISSN PRINT 2356-4962 ISSN ONLINE 2598-6538

pendapatan HAT dan bangunan kepada Kas Daerah; 2. Wajib pajak selanjutnya mengajukan proses permohonan penelitian dan pemeriksaan BPHTB pada Badan Pendapatan Daerah Kota Malang, selanjutnya jika sudah mendapatkan rekomendasi dapat melakukan verifikasi dan dapat divalidasi jika dianggap benar. Data untuk permohonan penelitian dan pemeriksaan antara lain: i. Tarif dan NPOPTKP wajib sinkron dengan yang ditentukan; ii. Pemenuhan yang dilaksanakan wajib sinkron dengan metadata pajak; iii. Tidak ditemukan pajak terutang PBBP2 sewaktu 5 (lima) tahun terakhir. Yang berwenang melakukan pemeriksaan kepatuhan pemenuhan kewajiban BPHTB yaitu Kepda atau pejabat yang dipilih, pengecekan terhadap wajib pajak atau pihak-pihak yang terkait meliputi pengecekan terhadap berkas dan keterangan-keterangan yang ada kaitannya dengan objek pajak; 3. Wajib Pajak wajib menyerahkan BPHTB berbarengan dengan pelunasan BPHTB terutang kepada Bendahara Penerimaan Bapenda Kota Malang; 4. Bendahara Penerimaan Bapenda Kota Malang menerima permohonan BPHTB dan uang pemenuhan BPHTB terutang yang didapat dari WP serta meneliti dan mengecek keseluruhan pengisian BPHTB dan kesepadanan total nilao BPHT terutang dengan uang pemenuhan WP; 5. Disahkannya SSPD BPHTB oleh Bendahara Penerimaan Bapenda Kota Malang yang pada lembaran 4, 5, dan 6 disimpan serta lembaran 1-3 diserahkan kembali pada WP.

\section{Persepsi masyarakat dari aspek substansi kebijakan yang dikeluarkan Bapenda Kota Malang}

Dalam Perda Kota Malang tentang BPHTB ini tidak mengatur mengenai penelitian dan pemeriksaan yang harus menyelesaikan seluruh kewajiban perpajakan, dimana dalam peraturan tersebut harus menyelesaikan pembayaran Pajak Bumi dan Bangunan 5 tahun terakhir. UU PDRD menjelaskan hubungan antara instansi pemerintah sebaai penyelengara administrasi orang banyak dan pribadi atau masyarakat penerima layanan umum.

Kewajiban yang dipunyai pemerintah dalam pemberian pelayanan yang sebaik-baiknya kepada masyarakt merupakn hakmasyarakat secara filosofis. Sehingga dapat diperoleh simpulan bahwa tugas negara dan pemerintah adalah agar terciptanya kesejahteraan rakyat Indonesia yang tercermin pada UUD NRI 1945.

Mengenai aspek substansi dari kejelasan hak WP dalam melakukan penelitian dan pengecekan sudah cukup jelas karena sudah diatur dalam Perda BPHTB Kota Malang, namun mengenai kebijakan yang dikeluarkan Bapenda Kota Malang yang mengharuskan untuk menuntaskan seluruh kewajiban pembayaran pajaknya yaitu tidak terdapatnya pajak terutang PBBP2, mengenai kebijakan tersebut baru diketahui setelah mengajukan rekom BPHTB yang mana diketahuinya terdapat PBBP2 yang belum dibayar 10 tahun terakhir yang mengakibatkan wajib pajak tidak mendapatkan rekom BPHTB untuk itu perlu dibayar terlebih dahulu PBBP2 terutangnya (Jovita, 2020).

Di sisi lain aspek substansi dari kejelasan standar waktu, secara umum bahwa standar waktu yang ditetapkan oleh Bapenda dalam proses penelitian dan pengecekan BPHTB terkadang memakan waktu lama, mengenai proses penelitian dan pemeriksaan BPHTB cukup dapat dimengerti berdasarkan kepentingan Bapenda, namun WP menginginkan ketepatan waktu dalam menerima hasil rekom tersebut (Laksmoko, 2020).

Wajib pajak berpendapat alur dalam proses layanan sampai proses menerima hasil rekom BPHTB bisa dipahami dan diikuti, namun WP masih kurang memahami mengenai kebijakan yang dikeluarkan pajak terutang PBBP2 dan" mengenai nilai BPHTB yang ditetapkan kadang kalanya melampaui jumlah yang ditulis dalam blanko BPHTB. WP secara positif menerima struktur dan besaran tariff yang ditentukan, karena proses 


\section{Asas certainty dalam mekanisme pembayaran kewajiban bea perolehan hak atas tanah dan bangunan \\ Riskha Indah Respati, Indah Dwi Qurbani, R. Imam Rahmat Safi'i}

pemungatan dan tarif semuanya secara administrasi tercanturm dalam Undang-Undang tentang PDRD dan pula termuat dalam Perda Kota Malang tentang BPHTB (Ari, 2020).

Menurut WP kesesuaian filosofi, prinsip pungutan, dan kewenangan pemerintah jauh dari prinsip yang dimuat dalan undang-undang, dikarenakan Bapenda dalam tindaakannya, melebihi apa yang bisa dilakukan dari WP, lantaran strategi ekstensifikasi dalam menggali sumber-sumber penerimaan rekom BPHTB yang dilaksanakan berbeda dengan kebijakan pokok nasional, yang mana rekom BPHTB menurut WP dilaksanakan sekadar untuk mngeduk perolehan daerah, tanpa menganalisa serta menjalankan fungsi fiskal lainnya yang tidak membebankan bagi masyarakat.

Selain itu, penerapan penuntutan aktif secara besar-besaran dilakukan terhadap WP BPHTB, dimana dalan proses penagihan pada pembetulan sebelum dilakukan validasi BPHTB. Bapenda Kota Malang melakukan proses pemeriksaan bahkan sama sekali tidak menerbitkan surat ketetapan pajak, artinya sebelum masuk berkas BPHTB tersebut, WP dapat menanyakain pajak yang harus mereka bayar ke Bapenda Kota Malang, Mengenai besarnya pajak BPHTB langsung ditentukan oleh aparat Bapenda, artinya WP tidak diairahkan atas kesadaran sendiri dalam mengungkapkan laporannya tentang ketidak benaran pengisan Rekom BPHTB yang telah disampaikan sesuai keadaan yang sebenarnya. Sehingga timbuil kesan terjadi negosiasi dalam pemenuhan pajak dan pelunasan BPHTB bukan lagi bersifat self assesement tapi oficial assesement.

Tindakan Badan Pendapatan Daerah Kota Malang yang dilaksanakan dalam bentuk mengeluarkan keputusan (beschikking) dalam penelitian dan pengecekan menurut WP selalu bersifat individual and concrrete. Proses dalam praktek pelaksanan penelitian dan pengecekan, seringkali ditemui syarat penelitian dan pengecekan yang memiliki karakteristik berbeda dengan peraturan" perundang-undangan.

Syarat penelitian dan pemeriksaan BPHTB yang mengharuskan WP untuk menuntaskan seluruh kewajiban pelunasan pajaknya dapat dikatakan sebagai peraturan kebijakan, dimana dikatsakan tidak terhindar dari suatu badan/pejabat tata usaha negara yang berkepentingan, mengartikan kebijaksanaannya dalam beraneka ragam bentuk juridische regels ysng tergolong seperti pengumuman, regulasi, pedoman, dan surat edaran, hsl ini lah yang dinamakan Freies Ermessen (Hadjon, 2005).

Suatu kelonggaran administrsi negara di dalama melaksanakan suatu gerakan beraksi atau tidak agar terwujud tujuan atau manfaat khusus/ doelmatigheid tidak sesuai acuam yang ditetapkan. Akan tetapi tidak langsung dapat dilaksanakan sesuatu yang bertentangan dengan hukum. Pengaturan terhadap asas Freies Ermessen yaitu selalu mengedepankan prinsip umum penyelenggaraan tata laksana negara yang relevan (Manan, 2006).

Dari hasil wawancara dengan beberapa wajib pajak disimpulkan bahwa apapupn itu keputusan atau peraturan yang bersifat kebijakan yang dikeluarkan oleh Bapenda Kota Malang, bisa dibuat asalkan ada konsistensi dari lembaga yang membuatnyasupaya tidak bertentangan dengan peraturan yang berada diatasnya. Selain itu seharusnya terdapat inovasi sistem yang lebih baik untuk menjauhi bertentangannya kaidah dan tidak adanya dualisme fungsi peraturan, karena terdapat kaidah yang bisa berfungsi sebagai beschikking dan regeling.

Selain itu, bukan berarti masyarakat yang tidak melaksanakan substansii kaidah kebijakan tersebut tidak dikenai "sanksi hukum". Setiap perilaku masyarakat yang tidak dilandasi substtansi peraturan kebijaikan, tentu akan memperoleh konsekuensi khusus. Apabila fiskus memiliki otoritas 


\section{Jurnal Cakrawala Hukum, Volume 11 No. 3 Desember 2020}

ISSN PRINT 2356-4962 ISSN ONLINE 2598-6538

membuat suatu peraturan kebijikan, maka dari itu fiskus memiliki otoritas untuk menerapkan konsekuiensi bagi setiap perilaku masyarakat yang melanggar substansi kaidah kebijakan tersebut.

\section{Penerapan asas certainty dalam meka- nisme pembayaran kewajiban BPHTB}

Bagi petugas pajak dan wajib pajak kepastian tentunya harus ada. Kepastian dalam asas certainty berupa orang perorangan yang layak dijatuhi pajak, total pajak yang harus dilunasi, serta dengan cara apa total pajak terutang tercantum wajib dipenuhi.

Penelitian serta pemeriksaan BPHTB, dalam hal ini BPHTB dalam pelaksanaannya oleh Badan Pendapatan Daerah Kota Malang, dilakukan untuk setiap BPHTB yang diserahkan oleh wajib pajak ke BAPENDA Kota Malang, dengan wajib pajak atau kuasa dari wajib pajak turut melampirkan formulir penyampaian BPHTB, beserta dengan kelengkapan surat ataupun dokumen pendukung lain, seperti fotocopy sertipikat, fotocopy identitas wajib pajak, fotokopi STTS PBB 5 tahun terakir, dan fotocopy PPh Final.

Pada Pasal 31, menjelaskan bahwa fiskus yang dipilih harus mengadakan kegiatan pengkajian BPHTB yang diserahkan oleh Wajib Pajak. Pengkajian ini tentunya wajib memprioritaskan tarif dan NPOPTKP sesuai yang telah ditentukan, pembayarannya harus sinkron dengan keterangan basis pajak, dan tidak ditemukannya pajak terhutang PBBP2 5 tahun terakhir, serta jika ditemukan pajak terhutang maka WP wajib menyelesaikan pajak terutang tersebut.

Dalam permohonan penelitian dan pemeriksaan BPHTB salah satu syaratnya menyelesaikan pajak terutang PBBP2 5 tahuin terakhir. Sehingga wajib pajak sebelum melakukan pembayaran BPHTB patut menyelesaikan PBBP2 5 tahun terakhir, yang telah diatur dalam Perda Kota Malang tentang BPHTB.
Dalam permohonan penelitian dan pemeriksaan BPHTB saat ini Bapenda Kota Malang telah mengeluarkan kewenangan yang mengatur wajib pajak sebelum membayar BPHTB harus menyelesaikan seluruh kewajiban perpajakannya yang mana harus menyelesaikan keseluruhan pajak terutang PBBP2. Dalam hal ini asas certainty belum diterapkan dengan baik, yang mana belum adanya kepastian hukum, yakni undang-undang harus nyata, mudah dipahami, serta tidak berisi makna ganda atau memberkan kesempatan menafsirkan lain, uraian yang limitatif lebih diutamakan daripada yang emunsiatif, terdapat jaminan hukum yaitu perlindungan terhadap WP, terdapat kepastian terkait subyek pajaknya, serta terdapa suatu kepastian tentang prosedur dan waktu yang pasti membayar pajak (Anshari, 2007).

Berdasarkan data dari Bapenda Kota Malang pada saat rekom BPHTB terdapat adanya kekurangan bayar BPHTB pada bulan Pebruari 2020 dari "706 BPHTB terdapat 164 BPHTB kurang bayar atau sebesar: 23,22\%, sedangkan bulan Maret 2020 dari 764 BPHTB terdapat 352 BPHTB kurang bayar atau 46,07\%." Dari data tersebut menggambarkan dari hasil penelitian dan pemeriksaan BРHTB termuat kekurangan pembayaran, namun bisa jadi WP wajib melunasi lebih dari yang diatur di dalam Perda Kota Malang. Wajib pajak merasa dirugikan karena harus melunasi pajak yang lebih besar.

Masalah yang timbul berkaitan terhadap pembayaran kewajiban perpajakan rekom BPHTB, yang berimbas ketidakpastian jangka waktu pembayaran Pajak Bumi dan Bangunan Perkotaan untuk rekom BPHTB yang digunakan manakala terjadi perbedaan antara peraturan perundangundangan yaitu Perda dengan penafsiran Badan Pendapatan Daerah, berimbas memperhambat proses pendaftaran peralihan HAT. Agar terwujud kepastian dalam PBBP2 saat rekom BPHTB, maka butuh suatu kepastian mengenai jangka waktu pembayaran yang ditetapkan oleh fiskus. 


\section{Asas certainty dalam mekanisme pembayaran kewajiban bea perolehan hak atas tanah dan bangunan \\ Riskha Indah Respati, Indah Dwi Qurbani, R. Imam Rahmat Safi'i}

Dibutuhkan adanya kepastian BPHTB pada permohonan penelitian dan pemeriksaan untuk menilai kecermatan, fungsi fiskus dalam hal ini sebagai pengamat BPHTB supaya WP dapat memenuhi tanggung jawab sesuai dengan peraturan perundang-undangan. Pengamatan oleh fiskus dengan menimbang-nimbang pajak terhutang yang dihitung sendiri WP dengan pajak terhutang yang diatur Perda. Apabila ada disparitas antara penilaian WP dan Undang-undang, alhasil fiskus dapat mengeluarkan STP.

Mengenai substansi UU PDRD menjelaskan mengenai pemungutan pajak tidak boleh ditetapkan dengan kaidah lebih rendah dari Perda, seperti contohnya keputusan/kebijakan oleh kepala daerah. Lebih lagi kebijakan/keputusan yang dikeluarkan hanya hanya berupa kebijakan secara perkataan saja.

Supaya penerapan asas certainty dalam mekanisme pembayaran kewajiban perpajakan ini berjalan sesuai yang diharapkan, maka Badan Pendapatan Daerah Kota Malang dimana kedepan perlu mengacu pada Perda ataupun Perwilbertujuan untuk tercapainya kepastiain hukum bagi WP dalam membayar BPHTB. Penerapan asas certainty dalam mekanisme pembayaran kewajiban BPHTB dapat memberi peningkatan pemasukan PAD Kota Malang, dengan bertambahnya jumlah pajak yang wajib disetor/dibayar oleh WP, akan menghasilkan pemasukan bagi PAD Kota Malang.

\subsection{Pengaturan mekanisme pembayaran kewajiban BPHTB sesuai asas certainty}

Pengaturan terkait pembentukan peraturan perundang-undangan telah diatur dalam UndangUndang dan telah ada ketentuan evaluasi dan analisis peraturan perundang-undangan. Hal tersebut dilakukan untuk mengidentifikasi dan mengharmonisasi kompleksitas berbagai Peraturan Perundang-undangan, ada proses singkronisasi dan harmonisasi peraturan perundang-undengan.
Artinya dalam mekanisme tersebut pada tahapan dalam pembentukannya sejak perencanaan hingga pengundangannya dilaksanakan dan dilalui dengan benar maka akan menghasilkan peraturan perundang-undangan yang baik (Qurbani, 2020).

Pengaturan mengenai mekanisme pembayaran kewajiban BPHTB diatur di dalam UU PDRD, jenis pajak yang diganti kewenangan pemungutannya dari pemerintahpusat ke pemerintah daerah adalah BPHTB. Sebelum diundangkannya UU PDRD, BPHTB yaitu pajak yang pemungutannya dilakukan oleh pusat serta hasil penerimaan sebagian besar dialokasikan kepada kota/kab. Hal ini tentunya berdampak pada pemerintah daerah dalam menyelenggarakan pemerintahannya serta memberikan pelayanan terhadap masyarakat. Tentunya berdasarkan atas ketentuan tersebut "pajak BPHTB yang awalnya dipungut dan dikelola oleh pemerintah pusat saat ini dipungut dan dikelola sendiri oleh pemerintah kabupaten/kota (Wiryawan, 2018).

Sebagai langkah nyata dari adanya pengalihan pajak pusat menjadi pajak daerah tersebut, pemerintah daerah dalam menindaklanjutinya dengan membentuk sebuah peraturan daerah. Kota Malang termasuk Pemerintah Daerah yang sudah membuat Perda tentang BPHTB. Segala jenis ketentuan-ketentuan tentang pajak BPHTB tersebut oleh Kota Malang dituangkan dalam Peraturan Daerah tentang BPHTB.

Dalam pemungutan BPHTB menggunakan sistem pembayaran pajak yang berdasarkan sistem pemungutan, maka dari itu WP dapat menghitung pajak dan melaporkan sendiri dengan sebutan self assesment system. Dalam hal ini WP diharapkan selalu aktif menghitung dan melaporkan pajak yang belum dibayar tanpa keterkaitan pihak fiskus. Pada sistem tersebut untuk memberikan suatu kepercayaan terhadap WP demi memajukan kesadaran untuk membayar pajak serta kapasitas WP dalam menyetorkan pajaknya. 


\section{Jurnal Cakrawala Hukum, Volume 11 No. 3 Desember 2020}

ISSN PRINT 2356-4962 ISSN ONLINE 2598-6538

Sistem self assessment dalam pemungutan BPHTB adalah suatu proses dari pengisian serta pengambilan BPHTB, kemudian dilakukan proses penghitungan dan penyetoran ke Kas Negara. Berlangsungnya dengan baik sistem self assessment diperlukan adanya syarat WP, antara lain Tax consciousness, Tax mindedness, Tax disciplin. Sebelum dilakukannnya pembayaran BPHTB wajib pajak melakukan penelitian dan pemeriksaan BPHTB kepada Bapenda, dalam hal ini terdapat kebijakan untuk menyelesaikan pembayaran kewajiban perpajakan yaitu menyelesaiakn seluruh pajak terutang PBBP2. Berbeda halnya dengan Perda Kota Malang tentang BPHTB bahwa salah satu syarat penelitian dan pemeriksaan BPHTB yaitu tidak terdapatnya pajak terutang PBBP2 selama 5 tahun terakhir. Dalam hal ini sistem self assessment belum diterapkan karena wajib pajak sudah menghitung sendiri pajak PBB yang akan dibayar namun Bapenda memberikan kebijakan yang mengharuskan pembayaran keseluruhan PBBP2 terutang.

Apabila disangkut pautkan dengan pemeriksaan berdasarkan kaidah Perda tentang BPHTB Kota Malang dengan ini pemeriksaan digunakan oleh fiskus untuk menilai ketertiban pemenuhan kewajiban pembayaran BPHTB bagi WP, serta menjalankan ketentuan kaidah yang terdapat di Perda. Dalam menilai ketertiban pemenuhan kewajiban pembayaran BPHTB daerah wajib melaksanakan ketentuan dengan berpatokan pada acuan dasar pemeriksaan, dengan persiapen yang baik sesuai dengan tujuan dilakukannya pemeriksaan yang berdasarkan kaidah.

Perbedaan multitafsir yang sering terjadi adalah tentang penelitian dan pemeriksaan BPHTB. Berdasarkan penafsiran penelitian dan pemeriksaan BPHTB dari Bapenda bahwa penelitian dan pemeriksaan itu sendiri adalah keseluruhan proses kegiatan meneliti, mengumpulkan dan mengolah metadata, keterangan yang diberikan WP, serta informasi yang dijalankan secara objektif dan propesional berdasarkan ketentuan dasar dalam kesesuaian semua dokumen pendukung dan juga kesesuaian metadata mengenai objek BPHTB. Tujuan penelitian serta pemeriksaan menurut Bapenda yaitu sebagai suatu pengaturan untuk menilai ketertiban pemenuhan kewajiban pembayaran BPHTB serta dengan bertujuan menjalankan ketentuan Perda yang terdiri dari penelitian, penyamaan data atau mengumpulkan data yang berkesinambungan dengan tujuan penelitian dan pemeriksaan BPHTB.

Pembentukan instrument pajak tentunya tidak terlepas dari prinsip pemungutan pajak, salah satunya yaitu asas certainty. Menurut Rochmat Soemitro dan Dewi Kania Sugiharti dalam bukunya yang berjudul "Asas Dan Dasar Perpajakan" yàng menjelaskan bahwa kepastian hukum adalah tujuan yang ingin dicapai oleh kaidah perundangundangen. Dalam membentuk Undang-Undang yang mengikat umum, patut diupayakan agar kaidah di dalam undang-undang itu mudah dipahami, pasti, tegas serta tidak berisi makna ganda atau memberkan kesempatan menafsirkan lain (Soemitro, 2004). Asas certainty bertujuàn agar pemungutan pajak tetap dalam prosedur yang benar dan tidak ada penyelewengan. Terkait secara formiil wajib mengenakan pajak berpegang pada undng-undang, untuk merencanakan undangundangnya wajib diupayakan terlaksananya keadilan dalam pemungutan pajak, memberikan kepastian hukum kepada wajib pajak. Untuk itu, pembuat undang-undang pajak harus menguasai legal drafting dan yang harus menjadi perhatian dalam pembuat undang-undang agar ada kepastian hukum, yakni undang-undang perlu mudah dipahami, pasti, tegas serta tidak berisi makna ganda atau memberikan kesempatan menafsirkan lain dan jelas terhadap tiap pasal, tanggungan/jaminan hukum berbentuk perlindungan bagi WP, terdapat kepastian pada objek pajak, subjek pajaknya, nilai pajak yang wajib dibayar, dan kepastian tentang cara dan saat membayar pajak. 


\section{Asas certainty dalam mekanisme pembayaran kewajiban bea perolehan hak atas tanah dan bangunan \\ Riskha Indah Respati, Indah Dwi Qurbani, R. Imam Rahmat Safi'i}

Dalam kaitanya dengan persoalan BPHTB, maka kepastian hukum bàgi WP merupàkàn sàlàh satu pendekatan untuk melindungi wajib pajak. Agar kepastian hukum wajib pajak bisa dilaksanakan dengan disiplin, konstan, dàn bertànggung jàwàb alhasil dibutuhkan kaidah hukum yàng harmonis dengàn perkembàngàn dimàsyàràkàt.

Perda Kota Malang mengatur secara pasti dan gamblang terkait objek, suibjek, alas penilaian dan jumlah BPHTB yang bharus dibayar, serta mengordinasikan yang berangkaian dengan tata laksana pemungutannya. Permohonan Penelitian dan Pemeriksaan BPHTB di Kota Malang adalah tingkatan dalam mekanisme tindakan tata laksana. Maksud dari tindakan tersebut guna mendapatkan, mengakumulasi, memenuhi, menatausahaan, serta mengkaji kebenaran estimasi pembayaran BPHTB terutang yang wajib disetorkan. Mekanisme ini tergolonhg dalam inventarisasi objak dan subjek PBBP2 dilaksanakan oleh Bapenda Kota Malang. Perolehan dari aktifitas penghitungan dipergunakan sebagai pembangunan atau memiara basis metadata SISMIOP, untuk mewujudkan metadata PBBP2 yang tepat, upgrade, dan terbaru dengan keadaan saat ini, maka dari itu diinginkan dapat terwujudnya PBBP2 yang lebih seimbang dan menyeluruh, disiplin tata laksana, dapat memberikan terlaksananya kepastian dan perolehan PBBP2, serta memberikan fasilitas terhadap WP.

Secara substansi Perda Kota Malang tentang BPHTB belum mengacu terhadap asas certainty karena terdapatnya peraturan yang mengatur mengenai permohonan penelitian dan BPHTB tidak berdasarkan Perda Kota Malang, karena terdapatnya kebijakan yang dikeluarkan oleh Bapenda Kota Malang untuk menyelesaikan seluruh kewajiban perpajakan PBBP2.

Sehingga dapat dikatakan bahwa asas certainty diperlukan dalam mekanisme pembayaran kewajiban perpajakan BPHTB. Menurut peneliti pengaturan kedepan tentang mekanisme pemba- yaran kewajiban BPHTB di Kota Malang seharusnya lebih mengacu pada Perda Kota Malang tentang BРHTB dan melihat sesuai dengan perkembangan perilaku masyarakat. Pada konteks ini asas certainty yang dimaksud peneliti, dapat memberikan penguatan terhadap kepastian masyarakat atau wajib pajak di Kota Malang.

Keputusan atau kebijakan yang dikeluarkan Bapenda Kota Malang untuk WP seharusnya berpedoman pada kaidah perundang-undangen. Maka dari itu dibutuhkan inspeksi terhadap keputusan/kebijakan yang dimaksudkan untuk mengukur terhadap perilaku kepada WP yang ikut serta melakasanakan sesuai dengan kaidah dan menjalankan kepastian hukum secara efisien bisa dilaksanakan oleh lembaga negara.

\section{Simpulan}

Dalam penerapan mekanisme pembayaran kewajiban BPHTB belum diterapkannya asas certainty secara ideal di dalam peraturan perundangundangan tentang pemungutan pajak di Kota Malang dengan adanya peraturan yang mengharuskan wajib pajak membayar seluruh kewajiban perpajakan terkait permohonan BPHTB.

Pengaturan ideal mekanisme pembayaran kewajiban BPHTB sesuai asas certainty: a. Dalam pemungutan BPHTB di Kota Malang pada kenyataannya kurang berjalan dengan baik yang mana menggunakan sistem official assessment sehingga perlu dikembalikan pada sistem yang seharusnya yakni sistem self assessment, agar menimbulkan kepastian masyarakat dan lebih adanya payung hukum terhadap adanya kurang bayar. b. Pembaharuan dan penyesuaian dalam penetapan Nilai Jual Objek Pajak (NJOP) yang dilakukan oleh penilai PBBP2 dengan melakukan analisis terhadap transaksi jual beli tanah dan atau bangunanyang terjadi untuk menghasilkan NJOP bumi/m2 yang akan digunakan untuk penetapan NJOP. Dalam hal ini bertujuan untuk meminimalisir 


\section{Jurnal Cakrawala Hukum, Volume 11 No. 3 Desember 2020}

ISSN PRINT 2356-4962 ISSN ONLINE 2598-6538

ketimpangan NJOP yang ada di PBBP2 dengan NJOP yang nantinya di dalam SSPD BPHTB pada saat peralihan.

\section{Daftar pustaka}

Alink, Matthis and Victor van Kommer. 2011. Handbook on Tax Administration, IBFD, H.J.E. Wenckebachweg 210, 1096 AS Amsterdam, The Netherlands, PO. Box 20237, 1000 HE Amsterdam.

Anshari, Tunggul. 2007. Ilmu Hukum Pajak. Setara Press. Malang.

Hartoyo, Harry dan Untung Supardi. 2010. Membedah Pengelolaan Administrasi PBBP2 serta BPHTB. Mitra Wacana Media. Jakarta.

Intan, L.C., 2016. Akibat pelanggaran oleh notaris terhadap pembuatan akta notariil. Jurnal Cakrawala Hukum, 7(2), pp.206-215.
Peters, Bruno. 2005. The Concept of Tax. EATLP Congress, Naples, Caserta.

Qurbani, Indah Dwi. 2019. RUU Omnibus Law Cipta Kerja dan Problematikanya Di Sektor Energi Dan Sumber Daya Mineral.

Soemitro, Rochmat dan Dewi Kania Sugiharti. 2004. Asas Serta Dasar Perpajakan I. Refika Adutama. Bandung.

Wikantha, A.A.B.M., 2017. Peran majelis pengawas dan kehormatan terhadap notaris yang membuat akta perjanjian nominee. Jurnal Cakrawala Hukum, 8(2), pp.181-190.

Wiryawan, I Gusti Agung Putra. 2018. Pengaturan Tentang Pengenaan BPHTB Atas Hibah Wasiat. Denpasar. Magister Kenotariatan, Universitas Udayana, Jurnal Ilmiah Magister Kenotariatan. 